\title{
Wpływ strategii wzorcowania w analizach chromatograficznych gazu ziemnego na niepewność wyznaczania ciepła spalania gazu
}

\begin{abstract}
W artykule przeanalizowano, jak przyjęcie różnych strategii wzorcowania wpływa na niepewność ciepła spalania gazu wyznaczonego na podstawie jego składu. Analizę tę przeprowadzono na przykładzie gazów ziemnych należących do grupy E. Poddano jej dwie strategie wzorcowania: wzorcowanie jednopunktowe oraz wzorcowanie wielopunktowe z użyciem najprostszego wielomianu pozwalającego na odpowiednie dopasowanie do danych.
\end{abstract}

Słowa kluczowe: ciepło spalania, niepewność, analiza chromatograficzna gazu ziemnego.

\section{Impact of calibration strategy in chromatographic analysis of natural gas for the uncertainty of the determination of heat of combustion}

\begin{abstract}
This article examined how various calibration strategies affect the uncertainty of the heat of gas combustion determined on the basis of its composition. The analysis was conducted on the example of natural gases belonging to the E group. Two calibration strategies were analyzed: single point calibration and multipoint calibration using the simplest polynomial which allowed an adequate fit to the data.
\end{abstract}

Key words: heat of combustion, uncertainty, chromatographic analysis of natural gas.

\section{Wstęp}

Analizy gazu ziemnego, które pozwalają na oznaczenie jego głównych składników takich jak: $\mathrm{N}_{2}, \mathrm{CO}_{2}$ (IV) i węglowodorowy $\mathrm{w}$ zakresie $\mathrm{C}_{1}-\mathrm{C}_{6+}$, prowadzone są najczęściej w celu uzyskania informacji dotyczących parametrów energetycznych gazu, w tym ciepła spalania. Dane te mogą być następnie wykorzystywane do prowadzenia rozliczeń gazu w jednostkach energii, rozliczeń wielkości emisji $\mathrm{CO}_{2}(\mathrm{IV})$ czy też oceny jakości gazu $[3,4]$. Podczas analiz chromatograficznych gazu stosowana może być jedna z dwóch podstawowych strategii wzorcowania:

- wzorcowanie wielopunktowe, gdzie krzywe wzorcowania poszczególnych składników mogą być aproksymowane jednym $\mathrm{z}$ wielomianów $\left(1-3^{\circ}\right)$,

- wzorcowanie jednopunktowe, gdzie funkcja wzorcowania aproksymowana jest prostą przechodzącą przez początek układu współrzędnych oraz jeden punkt pomiarowy.
Pierwszą z wymienionych strategii wzorcowania wykorzystuje się jedynie w niektórych stacjonarnych laboratoriach. W analizie gazu ziemnego o wiele częściej stosuje się wzorcowanie jednopunktowe, które wykorzystuje się zarówno w chromatografach działających w trybie on-line, jak i w niektórych chromatografach laboratoryjnych. Na podstawie wyników wielopunktowego wzorcowania można wyznaczyć rzeczywistą funkcję wzorcowania, która obrazuje zależność odpowiedzi detektora od stężenia analitu w badanej próbce. Zależność ta, szczególnie dla szerokiego zakresu stężeń, nie musi być liniowa. Mimo to często rzeczywistą funkcję wzorcowania upraszcza się do takiej postaci, aby stanowiła ona wielomian pierwszego stopnia. Działania te przyczyniają się do pogorszenia dokładności uzyskiwanych wyników analizy składu gazu i powiązanych z nimi niepewności. Należy pamiętać, że niepewność związana z przyjętą 
strategią wzorcowania jest tylko jedną za składowych w budżecie niepewności metody analitycznej, która przekłada się bezpośrednio na niepewność wyznaczonych parametrów energetycznych [1]. W chwili obecnej żadne akty prawne nie precyzują, z jaką niepewnością powinny być określone parametry energetyczne gazu wykorzystywane do prowadzenia rozliczeń w jednostkach energii $[8,9]$. Pewne wskazówki w tej kwestii znaleźć można w dokumentach normatywnych oraz Standardach Izby Gospodarczej Gazownictwa, które mówią, między innymi, że parametry energetyczne gazu, w tym ciepło spalania, powinny być podawane z dokładnością do $0,01 \mathrm{MJ} / \mathrm{m}^{3}[7,11]$. Oczywiste jest jednak, że światowe trendy w analityce gazu dążą do minimalizacji niepew- ności oznaczania składu gazu, a co za tym idzie - zmniejszenia niepewności wyznaczonych na podstawie składu gazu parametrów energetycznych. Dlatego też niepewności wynikające z przyjętej strategii wzorcowania powinny być możliwie jak najmniejsze. W niniejszym artykule przedstawiono, jak na niepewność wyznaczenia parametrów energetycznych gazu wpływa zastosowanie różnych strategii wzorcowania chromatografów gazowych wyposażonych w detektory TCD. Opisane badania zostały wykonane dla dwóch chromatografów gazowych laboratoryjnych wyposażonych w detektory TCD. Ze względu na to, że wyniki uzyskane dla obu chromatografów były zbliżone, $\mathrm{w}$ artykule przywołano rezultaty osiągnięte wyłącznie dla jednego $\mathrm{z}$ nich.

\section{Metodyka badań}

Podczas prowadzenia badań dla każdego z wzorcowanych chromatografów gazowych wyznaczono za pomocą certyfikowanych gazowych mieszanin wzorcowych rzeczywiste funkcje wzorcowania. Funkcje te zostały wyznaczone zgodnie z normą PN-EN ISO 10723:2013 Gaz ziemny - Ocena działania dotycząca układów analitycznych. Podczas wyznaczania krzywych wzorcowych pod uwagę wzięto znacznie szerszy zakres stężeń poszczególnych składników występujących w gazach ziemnych niż ten, który wynika z dotychczasowych badań gazów ziemnych należących do różnych grup. Takie założenie wzięło się stąd, że w przypadku laboratoriów stosujących wzorcowanie wielopunktowe chromatografów gazowych ten sam zestaw krzywych wzorcowych stosowany jest podczas analiz gazów ziemnych należących do różnych grup. Ze względu na to, że rzeczywiste funkcje wzorcowania chromatografów gazowych służących do analizy gazu ziemnego z reguły aproksymowane były jako wielomiany drugiego i trzeciego stopnia - w praktyce są bardzo rzadko wykorzystywane w rutynowych analizach gazu ziemnego - ocenie poddano dwie strategie wzorcowania uproszczone względem rzeczywistej funkcji wzorcowania. Oceniono:

- strategię A - wzorcowanie jednopunktowe z wykorzystaniem odpowiednio dobranej mieszaniny wzorcowej,

- strategię B - wzorcowanie wielopunktowe przeprowadzone w tym samym zakresie stężeń co rzeczywista funkcja wzorcowania, jednak aproksymowane akceptowalnym wielomianem możliwie najniższego stopnia.

Porównanie wyników ciepła spalania, otrzymanych przy użyciu składów gazów wyznaczonych za pomocą rzeczywistej funkcji wzorcowania oraz dwóch analizowanych strategii wzorcowania, pozwoliło na określenie wpływu strategii wzorcowania na niepewność wyznaczania parametrów energetycznych gazu.

\section{Wyznaczenie rzeczywistych funkcji wzorcowania}

Przed wykonaniem wzorcowania analizatora działającego w trybie on-line i wyznaczeniem rzeczywistej funkcji wzorcowania należy określić zakres analityczny metody chromatograficznej służącej do analizy składu gazu. Zakres ten powinien być nieznacznie szerszy niż spodziewany zakres stężeń poszczególnych składników w analizowanych gazach ziemnych [2]. Zakres analityczny metody służący do oznaczania składu gazów ziemnych należących do grupy E podano w tablicy 1. Określono go na podstawie badań jakości gazu ziemnego prowadzonych w latach 2011-2014. Ze względu na to, że w przypadku wzorcowania wielopunktowego najczęściej wykorzystuje się ten sam zestaw krzywych wzorcowych podczas analiz składu gazu ziemnego należącego do różnych grup (E, Lw, Ls), wzorcowanie wielopunk- towe chromatografu gazowego wykonano w znacznie szerszym zakresie, co zostało również przedstawione w tablicy 1 .

Dla każdego składnika oznaczanego w gazie ziemnym wykonano wzorcowanie wielopunktowe $\mathrm{z}$ wykorzystaniem dostępnych w laboratorium gazowych mieszanin wzorcowych (tablica 1). Liczba punktów wzorcowania dla poszczególnych składników była różna w zależności od zakresu pomiarowego. Wzorcowania dla poszczególnych składników wykonano w sposób periodyczny. Oznacza to, że gazowe mieszaniny wzorcowe wprowadzane są kolejno, a po zakończeniu analiz pierwszego wzorca badany był wzorzec następny [6]. Dla wszystkich składników i każdego poziomu stężeń wykonano po pięć analiz gazowych mieszanin wzorcowych tworzących jedną serię. Następnie wyniki zebrane w każdej 
Tablica 1. Zakres analityczny oraz zakres krzywych wzorcowych dla metody służącej do oznaczania składu gazu ziemnego należącego do grupy $\mathrm{E}$

\begin{tabular}{|l|c|c|c|c|}
\hline \multirow{2}{*}{ Składnik } & \multicolumn{2}{|c|}{$\begin{array}{c}\text { Zakres analityczny } \\
{[\% \mathrm{~mol} / \mathrm{mol}]}\end{array}$} & \multicolumn{2}{c|}{$\begin{array}{c}\text { Zakres krzywych wzorcowych } \\
{[\% \mathrm{~mol} / \mathrm{mol}]^{1}}\end{array}$} \\
\cline { 2 - 5 } & minimum & maksimum & minimum & maksimum \\
\hline Metan & 90,000 & 99,60 & 49,99000 & 97,88000 \\
\hline Etan & 0,040 & 4,80 & 0,10400 & 5,04500 \\
\hline Propan & 0,001 & 1,30 & 0,01005 & 5,04100 \\
\hline i-butan & 0,001 & 0,16 & 0,02030 & 0,04980 \\
\hline n-butan & 0,001 & 0,17 & 0,00906 & 0,50000 \\
\hline i-pentan & 0,001 & 0,15 & 0,01663 & 0,49380 \\
\hline n-pentan & 0,001 & 0,12 & 0,01128 & 0,05019 \\
\hline C $_{6+}$ & 0,001 & 0,31 & 0,01008 & 0,50380 \\
\hline Azot & 0,200 & 6,00 & 0,10000 & 44,88000 \\
\hline $\mathrm{CO}_{2}$ & 0,001 & 1,70 & 0,10030 & 5,00000 \\
\hline
\end{tabular}

${ }^{1}$ Stężenia poszczególnych składników dla zakresu krzywych wzorcowych zostały podane z taką liczbą cyfr znaczących, jaką podano w certyfikatach gazowych mieszanin wzorcowych stosowanych do wzorcowania chromatografów gazowych.

serii pomiarowej sprawdzono testem Q-Dixona - na obecność wartości odstających. Po usunięciu wartości odstających dla każdego składnika zebrano dane niezbędne do przeprowadzenia wzorcowania wielopunktowego, tj.: stężenie składnika w certyfikowanej gazowej mieszaninie wzorcowej wraz z niepewnością oraz średnią wielkość i odchylenie standardowe dla uzyskanych odpowiedzi detektora. Do obliczeń przyjęto jako niepewność stężenia wartość niepewności zgodnie z certyfikatem dołączonym do gazowej mieszaniny wzorcowej, natomiast jako niepewność sygnału odpowiedzi wybrano odchylenie standardowe uzyskane dla powtarzalnych przebiegów analitycznych. Przebieg krzywych wzorcowych dla wszystkich składników został wyznaczony przy użyciu zwalidowanego programu Xgenline 8.1, rekomendowanego w normie PN-EN ISO 6974-1:2012. Dla każdego ze składników krzywe wzorcowania aproksymowano trzema wielomianami: pierwszego, drugiego i trzeciego stopnia. Dla wszystkich uzyskanych w ten sposób wielomianów obliczono miarę dobroci dopasowania $\Gamma$, przyjmując, że funkcja wzorcowania jest akceptowalna, jeśli $\Gamma \leq 2$ [6]. W następnym kroku, spośród trzech wyznaczonych krzywych wzorcowych będących wielomianami pierwszego, drugiego i trzeciego stopnia, wybrano rzeczywistą funkcję wzorcowania. Przyjęto funkcję, dla której miara dobroci dopasowania krzywej wzorcowania do punktów doświadczalnych była najlepsza, czyli wskaźnik $\Gamma$ był najniższy. Jeżeli dwie krzywe wzorcowania charakteryzowały się identycznym wskaźnikiem $\Gamma$, wtedy jako rzeczywistą funkcję wzorcowania przyjmowano prostszą postać funkcji, czyli wielomian niższego stopnia. Wyniki przeprowadzonego wzorcowania wielopunktowego oraz dokonanych analiz zebrano w tablicy 2 .

W wyniku wzorcowania wielopunktowego dla każdego $\mathrm{z}$ analizowanych składników zostały wybrane rzeczywiste funkcje wzorcowania, charakteryzujące się możliwie najlepszym dopasowaniem krzywej do wyznaczonych doświadczalnie punktów wzorcowania. Rzeczywiste funkcje wzorcowania dla pięciu składników zostały opisane wielomianem trzeciego stopnia. Krzywe będące wielomianami drugiego stopnia przyjęto $\mathrm{w}$ trzech przypadkach, natomiast tylko dla dwóch składników (i-butanu i n-pentanu) jako rzeczywistą funkcję wzorcowania wybrano prostą opisaną wielomianem pierwszego stopnia.

Tablica 2. Wyniki wzorcowania wielopunktowego przykładowego chromatografu gazowego wyposażonego w detektor TCD

\begin{tabular}{|c|c|c|c|c|}
\hline $\begin{array}{c}\text { Liczba } \\
\text { punktów } \\
\text { wzorcowania }\end{array}$ & $\begin{array}{c}\text { Stopień } \\
\text { wielomianu }\end{array}$ & Wzór funkcji & $\begin{array}{c}\text { Miara } \\
\text { dopasowania }\end{array}$ & $\begin{array}{l}\text { Rzeczywista } \\
\text { funkcja } \\
\text { wzorcowania }\end{array}$ \\
\hline \multicolumn{5}{|c|}{ metan } \\
\hline \multirow{3}{*}{7} & $1^{\circ}$ & $\mathrm{S}_{\mathrm{i}}=76267,28 \mathrm{C}_{\mathrm{i}}+253819,57$ & $\Gamma=1,647$ & \multirow{3}{*}{ wielomian $3^{\circ}$} \\
\hline & $2^{\circ}$ & $\mathrm{S}_{\mathrm{i}}=85,701 \mathrm{C}_{\mathrm{i}}^{2}+62825 \mathrm{C}_{\mathrm{i}}+751524$ & $\Gamma=1,407$ & \\
\hline & $3^{\circ}$ & $\mathrm{S}_{\mathrm{i}}=21,272 \mathrm{C}_{\mathrm{i}}^{3}-4562,3 \mathrm{C}_{\mathrm{i}}^{2}+391493 \mathrm{C}_{\mathrm{i}}-6826962,92$ & $\Gamma=0,829$ & \\
\hline \multicolumn{5}{|c|}{ etan } \\
\hline \multirow{3}{*}{7} & $1^{\circ}$ & $\mathrm{S}_{\mathrm{i}}=116244 \mathrm{C}_{\mathrm{i}}-1796,9$ & $\Gamma=0,956$ & \multirow{3}{*}{ wielomian $3^{\circ}$} \\
\hline & $2^{\circ}$ & $\mathrm{S}_{\mathrm{i}}=326,44 \mathrm{C}_{\mathrm{i}}^{2}+115232 \mathrm{C}_{\mathrm{i}}-1378,3$ & $\Gamma=0,884$ & \\
\hline & $3^{\circ}$ & $S_{i}=616,38 C_{i}^{3}-3412,3 C_{i}^{2}+118513 C_{i}-1792,2$ & $\Gamma=0,713$ & \\
\hline
\end{tabular}


cd. Tablica 2

\begin{tabular}{|c|c|c|c|c|}
\hline $\begin{array}{c}\text { Liczba } \\
\text { punktów } \\
\text { wzorcowania }\end{array}$ & $\begin{array}{c}\text { Stopień } \\
\text { wielomianu }\end{array}$ & Wzór funkcji & $\begin{array}{c}\text { Miara } \\
\text { dopasowania }\end{array}$ & $\begin{array}{l}\text { Rzeczywista } \\
\text { funkcja } \\
\text { wzorcowania }\end{array}$ \\
\hline \multicolumn{5}{|c|}{ propan } \\
\hline \multirow{3}{*}{8} & $1^{\circ}$ & $\mathrm{S}_{\mathrm{i}}=142660 \mathrm{C}_{\mathrm{i}}-367,37$ & $\Gamma=1,144$ & \multirow{3}{*}{ wielomian $3^{\circ}$} \\
\hline & $2^{\circ}$ & $\mathrm{S}_{\mathrm{i}}=2261,9 \mathrm{C}_{\mathrm{i}}^{2}+138832 \mathrm{C}_{\mathrm{i}}-218,33$ & $\Gamma=0,766$ & \\
\hline & $3^{\circ}$ & $S_{i}=-965,37 C_{i}^{3}+6759,3 C_{i}^{2}+135475 C_{i}-105,36$ & $\Gamma=0,490$ & \\
\hline \multicolumn{5}{|c|}{ i-butan } \\
\hline \multirow{3}{*}{5} & $1^{\circ}$ & $\mathrm{S}_{\mathrm{i}}=171271 \mathrm{C}_{\mathrm{i}}-747,4$ & $\Gamma=0,542$ & \multirow{3}{*}{ wielomian $1^{\circ}$} \\
\hline & $2^{\circ}$ & $\mathrm{S}_{\mathrm{i}}=1546505 \mathrm{C}_{\mathrm{i}}^{2}+66718,9 \mathrm{C}_{\mathrm{i}}+748,28$ & $\Gamma=0,619$ & \\
\hline & $3^{\circ}$ & $\mathrm{S}_{\mathrm{i}}=-3400821,6 \mathrm{C}_{\mathrm{i}}^{3}+1172739,4 \mathrm{C}_{\mathrm{i}}^{2}+79657,3 \mathrm{C}_{\mathrm{i}}+611$ & $\Gamma=0,619$ & \\
\hline \multicolumn{5}{|c|}{ n-butan } \\
\hline \multirow{3}{*}{8} & $1^{\circ}$ & $\mathrm{S}_{\mathrm{i}}=195707 \mathrm{C}_{\mathrm{i}}-2211,8$ & $\Gamma>2,0$ & \multirow{3}{*}{ wielomian $3^{\circ}$} \\
\hline & $2^{\circ}$ & $\mathrm{S}_{\mathrm{i}}=63952 \mathrm{C}_{\mathrm{i}}^{2}+149916 \mathrm{C}_{\mathrm{i}}+84,202$ & $\Gamma=1,696$ & \\
\hline & $3^{\circ}$ & $\mathrm{S}_{\mathrm{i}}=352750 \mathrm{C}_{\mathrm{i}}^{3}-108363 \mathrm{C}_{\mathrm{i}}^{2}+165242 \mathrm{C}_{\mathrm{i}}-144,46$ & $\Gamma=0,982$ & \\
\hline \multicolumn{5}{|c|}{ i-pentan } \\
\hline \multirow{3}{*}{6} & $1^{\circ}$ & $\mathrm{S}_{\mathrm{i}}=192161 \mathrm{C}_{\mathrm{i}}-613,89$ & $\Gamma>2,0$ & \multirow{3}{*}{ wielomian $2^{\circ}$} \\
\hline & $2^{\circ}$ & $S_{i}=-74260 C_{i}^{2}+221935 C_{i}-1363$ & $\Gamma=1,902$ & \\
\hline & $3^{\circ}$ & $S_{i}=-423877 C_{i}^{3}+197135 C_{i}^{2}+185524 C_{i}-648,19$ & $\Gamma>2,0$ & \\
\hline \multicolumn{5}{|c|}{ n-pentan } \\
\hline \multirow{3}{*}{4} & $1^{\circ}$ & $S_{i}=118380 C_{i}-20,723$ & $\Gamma=0,873$ & \multirow{3}{*}{ wielomian $1^{\circ}$} \\
\hline & $2^{\circ}$ & $\mathrm{S}_{\mathrm{i}}=-42230,61 \mathrm{C}_{\mathrm{i}}^{2}+121028,89 \mathrm{C}_{\mathrm{i}}-47,34$ & $\Gamma=0,873$ & \\
\hline & $3^{\circ}$ & zbyt mała liczba punktów pomiarowych do wyznaczen & lomianu $3^{\circ}$ & \\
\hline \multicolumn{5}{|c|}{$\mathrm{C}_{6+}$} \\
\hline \multirow{3}{*}{5} & $1^{\circ}$ & $\mathrm{S}_{\mathrm{i}}=131381 \mathrm{C}_{\mathrm{i}}-1654$ & $\Gamma>2,0$ & \multirow{3}{*}{ wielomian $2^{\circ}$} \\
\hline & $2^{\circ}$ & $\mathrm{S}_{\mathrm{i}}=176048 \mathrm{C}_{\mathrm{i}}^{2}+59043 \mathrm{C}_{\mathrm{i}}-335,52$ & $\Gamma=2,000$ & \\
\hline & $3^{\circ}$ & wyznaczona funkcja nie jest monotoniczna & & \\
\hline \multicolumn{5}{|c|}{ azot } \\
\hline \multirow{3}{*}{7} & $1^{\circ}$ & $\mathrm{S}_{\mathrm{i}}=80052,74 \mathrm{C}_{\mathrm{i}}-41445,17$ & $\Gamma>2,0$ & \multirow{3}{*}{ wielomian $3^{\circ}$} \\
\hline & $2^{\circ}$ & $\mathrm{S}_{\mathrm{i}}=-460,72_{\mathrm{i}}^{2}+94155 \mathrm{C}_{\mathrm{i}}+6415,5$ & $\Gamma>2,0$ & \\
\hline & $3^{\circ}$ & $\mathrm{S}_{\mathrm{i}}=24,729 \mathrm{C}_{\mathrm{i}}^{3}-1653,1 \mathrm{C}_{\mathrm{i}}^{2}+107443 \mathrm{C}_{\mathrm{i}}-19154$ & $\Gamma=1,111$ & \\
\hline \multicolumn{5}{|c|}{ tlenek węgla(IV) } \\
\hline \multirow{3}{*}{7} & $1^{\circ}$ & $\mathrm{S}_{\mathrm{i}}=109113 \mathrm{C}_{\mathrm{i}}-1115,3$ & $\Gamma=0,975$ & \multirow{3}{*}{ wielomian $2^{\circ}$} \\
\hline & $2^{\circ}$ & $\mathrm{S}_{\mathrm{i}}=997,54_{\mathrm{i}}^{2}+105078 \mathrm{C}_{\mathrm{i}}-524,2$ & $\Gamma=0,550$ & \\
\hline & $3^{\circ}$ & $\mathrm{S}_{\mathrm{i}}=212,7 \mathrm{C}_{\mathrm{i}}^{3}-10400 \mathrm{C}_{\mathrm{i}}^{2}+109123 \mathrm{C}_{\mathrm{i}}-853,6$ & $\Gamma=0,695$ & \\
\hline
\end{tabular}

\section{Analiza wpływu strategii wzorcowania na dokładność oraz niepewność wyznaczania ciepła spalania}

Wyniki przedstawione w tablicy 2 pokazały, że w większości przypadków rzeczywiste funkcje wzorcowania są wielomianami trzeciego stopnia. Tak skomplikowane funkcje rzadko stosuje się w chromatografach laboratoryjnych i praktycznie nie można ich wykorzystać w chromatografach działających w trybie on-line. Bez wątpienia wybór in- nej, prostszej funkcji wzorcowania może prowadzić do uzyskania odmiennych wyników składu gazu, a w konsekwencji do różnic w wyliczonym na podstawie składu gazu cieple spalania. Dlatego też sprawdzono, jaki wpływ na otrzymywane wyniki ciepła spalania gazu ziemnego należącego do grupy E będzie miało zastosowanie dwóch uproszczonych 
strategii wzorcowania. Pierwszą ze strategii (strategia A) stanowiło wzorcowanie jednopunktowe gazową mieszaniną wzorcową - dobraną tak, aby spełniała założenia przedstawione w tablicy 3 .

Tablica 3. Wytyczne dotyczące doboru ilościowego składników wzorcowej mieszaniny gazowej [10]

\begin{tabular}{|c|c|}
\hline $\begin{array}{c}\text { Stężenie składnika } \\
\text { gazie ziemnym } \\
{[\% \mathrm{~mol} / \mathrm{mol}]}\end{array}$ & $\begin{array}{c}\text { Dopuszczalna względna różnica stężeń } \\
\text { danego składnika w gazie ziemnym } \\
\text { i wzorcowej mieszaninie gazowej } \\
{[\%]}\end{array}$ \\
\hline $0,001 \div 0,1$ & $\pm 100^{1}$ \\
\hline $0,1 \div 1,0$ & \pm 50 \\
\hline $1,0 \div 10,0$ & \pm 10 \\
\hline $10,0 \div 50,0$ & \pm 5 \\
\hline $50,0 \div 100,0$ & \pm 3 \\
\hline
\end{tabular}

${ }^{1}$ Minimalne stężenie składnika we wzorcowej mieszaninie gazowej powinno wynosić nie mniej niż 150 ppm.

Ze względu na fakt, że przedstawiony w tablicy 1 zakres analityczny, wynikający ze zmienności składu gazu i niezbędny do analiz gazów ziemnych z grupy E, jest bardzo szeroki, nie ma możliwości dobrania jednej gazowej mieszaniny wzorcowej tak, aby swoim składem objęła go w całości. Dlatego też w tej strategii wzorcowania gazowa mieszanina służąca do wzorcowania jednopunktowego chromatografu gazowego wyposażonego $\mathrm{w}$ detektor TCD została dobrana do średnich stężeń poszczególnych składników występujących w gazach ziemnych należących do grypy E. Druga z rozpatrywanych strategii wzorcowania (strategia B) przewidywała wykorzystanie wielopunktowej krzywej wzorcowania opisanej wielomianem możliwie najniższego stopnia, dla którego miara dopasowania $\Gamma$ nie przekraczała 2 . W celu sprawdzenia, jak wybór strategii wzorcowania wpływa na uzyskiwane wyniki składu gazu ziemnego i powiązane z nimi wartości ciepła spalania tego paliwa, wygenerowano przy użyciu programu GasTools (rekomendowanego w normie PN-EN ISO 6974-1:2012) 100 różnych składów gazu ziemnego odpowiadających składom gazów należących do grup E. Wykorzystując wygenerowane składy gazu ziemnego i rzeczywiste funkcje wzorcowania detektora, dla każdej ze strategii oszacowano, jaki wpływ na uzyskiwane wyniki wyznaczonych wartości ciepła spalania ma wybór innej strategii wzorcowania niż opartej na rzeczywistej funkcji wzorcowania. W tym celu dla wszystkich rozpatrywanych składów gazu ziemnego wyliczono, na podstawie rzeczywistej funkcji wzorcowania, wartość sygnału analitycznego dla każdego składnika. Następnie, wykorzystując te wartości, wyliczono stężenia poszczególnych składników w gazie, stosując dane z opisanych powyżej dwóch strategii wzorcowania (A i B).
Uzyskane w ten sposób składy gazu znormalizowano i wyliczono dla nich wartości ciepła spalania. Porównanie otrzymanych wyników z wartościami wyjściowymi pozwoliło określić wpływ wyboru strategii wzorcowania na dokładność otrzymywanych wyników. Przyjmując, że maksymalny błąd względny otrzymany dla danego zakresu stężeń poszczególnych składników w gazie jest błędem granicznym o rozkładzie jednostajnym (prostokątnym), oszacowano niepewność związaną $\mathrm{z}$ zastosowaną strategią wzorcowania, rozumianą jako [5]:

$$
u\left(H_{s}\right)=\frac{\Delta_{g r}}{\sqrt[2]{3}}
$$

gdzie:

$u\left(H_{s}\right)$ - niepewność ciepła spalania wynikająca z przyjętej strategii wzorcowania,

$\Delta_{g r}$ - błąd graniczny rozumiany jako maksymalny błąd względny uzyskany dla danej strategii wzorcowania w zakresie analizowanych stężeń.

Uzyskane dla gazów ziemnych należących do grupy $\mathrm{E}$ wyniki pozwoliły stwierdzić, że przy wykorzystaniu wzorcowania jednopunktowego (strategia A) otrzymane wyniki składu gazu w znacznym stopniu różnią się od składów wyjściowych, a co za tym idzie - wyliczone na ich podstawie ciepło spalania obarczone jest znacznym błędem, sięgającym nawet $1,4 \%$. W przypadku tej strategii wzorcowania średni błąd wyznaczonego ciepła spalania wynosił $0,4 \%$, czyli około $0,17 \mathrm{MJ} / \mathrm{m}^{3}$. Stosując strategie wzorcowania A, tylko w 13 przypadkach otrzymano wynik ciepła spalania obarczony błędem względnym poniżej $0,1 \%$. Taka sytuacja miała miejsce w przypadku gazów ziemnych zawierających niewielkie ilości węglowodorów $\mathrm{C}_{5+}$. Wyniki obarczone największym błędem względnym, przekraczającym $1 \%$, uzyskano w 13 przypadkach, w których analizowane były gazy ziemne o znacznych zawartościach węglowodorów $\mathrm{C}_{5+}$. W przypadku zastosowania do wzorcowania strategii B (czyli wzorcowania wielopunktowego) otrzymano wyniki zbliżone do wartości wyjściowych. Maksymalny błąd względny między założonym a otrzymanym ciepłem spalania gazu wynosił $0,1 \%$, czyli około $0,03 \mathrm{MJ} / \mathrm{m}^{3}$. Zastosowanie strategii B pozwoliło na uzyskanie $39 \%$ wyników ciepła spalania równych założonemu. Biorąc pod uwagę, że maksymalny błąd względny wyznaczonego ciepła spalania wynosił dla strategii $\mathrm{A}-1,4 \%$, natomiast dla strategii $\mathrm{B}-0,1 \%$, wykorzystując równanie (1), wyznaczono niepewność ciepła spalania wynikającą z zastosowania poszczególnych strategii wzorcowania. Niepewność ta w przypadku strategii A stanowi $0,8 \%$, natomiast dla strategii $\mathrm{B}-0,06 \%$.

Przeprowadzone badania wykazały, że zastosowanie wzorcowania jednopunktowego w przypadku detektorów TCD 
może prowadzić do powstawania znacznych błędów podczas wyznaczania ciepła spalania gazów ziemnych należących do grupy E. Wynika to najprawdopodobniej z tego, że zakres analityczny zmienności składu gazów jest bardzo szeroki. Z tego względu gazowa mieszanina wzorcowa, która posłużyła do wyznaczenia współczynników odpowiedzi dla strategii A, nie pokrywała całego szerokiego zakresu stężeń poszczególnych składników gazu. Dlatego też zdecydowano o zawężeniu przedziału analizowanych stężeń w stosunku do zakresów określonych w tablicy 1. Zakresy analizowanych stężeń zawężono w taki sposób, aby dobrana wcześniej gazowa mieszanina wzorcowa spełniała założenia przedstawione w tablicy 3 . Nowy analityczny zakres stężeń poszczególnych składników zaprezentowano w tablicy 4.

Stosowanie strategii wzorcowania A podczas oznaczania składu gazu ziemnego, w zakresie podanym w tablicy 1 , czyli w pełnym zakresie stężeń poszczególnych składników występujących w gazach ziemnych typu E, prowadziło do uzyskania znacznych błędów w oznaczonych stężeniach poszczególnych składników, a także w wyznaczonych ciepłach spalania. Błędy w zakresie ciepła spalania mieściły się w przedziale od 0 do 1,4\%. Zmniejszenie zakresu analizowanych stężeń do poziomu przedstawionego w tablicy 4, przeprowadzone w taki sposób, aby zastosowana do wzorcowania mieszanina gazowa spełniała założenia zawarte w tablicy 3, przyczyniło się do znacznego wzrostu dokładności ciepła spalania określanego z użyciem strategii A. W wąskim zakresie stężeń maksymalny błąd względny wyznaczonego
Tablica 4. Zawężony zakres analityczny

\begin{tabular}{|l|c|c|}
\hline \multirow{2}{*}{ Składnik } & \multicolumn{2}{|c|}{$\begin{array}{c}\text { Zawężony zakres analityczny } \\
\text { [\% mol/mol] }\end{array}$} \\
\cline { 2 - 3 } & minimum & maksimum \\
\hline Metan & 94,7690 & 99,4742 \\
\hline Etan & 1,0764 & 1,3156 \\
\hline Propan & 0,1405 & 0,4215 \\
\hline i-butan & 0,0010 & 0,0996 \\
\hline n-butan & 0,0010 & 0,1608 \\
\hline i-pentan & 0,0010 & 0,0333 \\
\hline n-pentan & 0,0010 & 0,0402 \\
\hline $\mathrm{C}_{6+}$ & 0,0010 & 0,0359 \\
\hline Azot & 1,0170 & 1,2430 \\
\hline $\mathrm{CO}_{2}$ & 0,0895 & 0,2685 \\
\hline
\end{tabular}

ciepła spalania dla gazów ziemnych należących do grupy $\mathrm{E}$ nie przekroczył $0,1 \%$, dodatkowo w przypadku $10 \%$ analizowanych gazów otrzymano wyniki równe założonym. Dla szerokiego zakresu stężeń taka sytuacja miała miejsce jedynie w $2 \%$ przypadków. Znaczna poprawa dokładności podczas wyznaczania ciepła spalania w przypadku tej grupy gazów przyczyniła się do istotnego zmniejszenia niepewności wyznaczania ciepła spalania na podstawie składu gazu, związanej z wyborem innej funkcji wzorcowania niż rzeczywista. Wyliczona na podstawie równania (1) niepewność ciepła spalania, związana z zastosowaniem strategii wzorcowania A dla gazów ziemnych należących do grupy E, wynosi $0,06 \%$.

\section{Podsumowanie}

Przeprowadzone badania wykazały, że większość rzeczywistych funkcji wzorcowania stanowiły wielomiany wyższego stopnia niż pierwszy. Zastosowanie skomplikowanych funkcji wzorcowania podczas rutynowej pracy chromatografu wiąże się z szeregiem utrudnień, a w przypadku chromatografów działających w trybie on-line - może być niemożliwe do wykonania. $\mathrm{Z}$ tego względu sprawdzono, jaki wpływ na dokładność oraz niepewność wyznaczania ciepła spalania ma zastosowanie podczas wzorcowania innej strategii niż opartej na rzeczywistej funkcji wzorcowania. Uzyskane wyniki pozwalają stwierdzić, że stosowanie jednopunktowej strategii wzorcowania chromatografów gazowych służących do analizy gazów ziemnych o szerokim zakresie zmienności składu może przyczyniać się do znacznego wzrostu niepewności ciepła spalania wyznaczonego na podstawie składu gazu. Zmniejszenie analitycznego zakresu stężeń pozwoliło na znaczące ograniczenie niepewności wyznaczonego ciepła spalania, z $0,8 \%$ dla całego zakresu stężeń do $0,06 \%$ dla ograniczonego zakresu stężeń. Natomiast stosowa- nie podczas wzorcowania chromatografów gazowych wyposażonych w detektory TCD wzorcowania wielopunktowego z aproksymacją krzywych wzorcowych wielomianem możliwie najniższego stopnia (strategia B) również prowadzi do zwiększenia niepewności wyznaczonego na podstawie składu gazu ciepła spalania. Jednak strategia ta charakteryzuje się znacznie mniejszym wkładem w niepewność niż strategia jednopunktowa. Niepewność wyznaczenia ciepła spalania związana $\mathrm{z}$ zastosowaniem strategii B dla gazów ziemnych należących do grupy E nie przekracza $0,06 \%$. Wartość ta może być osiągnięta dla całego zakresu stężeń.

Reasumując, wyniki przeprowadzonych badań pozwoliły stwierdzić, że możliwe jest wzorcowanie chromatografów gazowych służących do analizy składu gazu ziemnego na potrzeby wyznaczania jego parametrów energetycznych (np. ciepła spalania) z zastosowaniem funkcji innych niż rzeczywista funkcja wzorcowania. Jeśli prowadzone jest wzorcowanie wielopunktowe, w którym krzywe wzorcowania aproksymowane są wielomianem możliwie 
najniższego stopnia, dla którego $\Gamma<2$, wtedy składowa niepewności wyznaczonego ciepła spalania, wynikająca z zastosowanego sposobu wzorcowania, nie powinna przekroczyć $0,1 \%$. Dużą przewagą tej strategii wzorcowania nad strategią jednopunktową jest to, że niewielka wartość niepewności uzyskiwana jest w szerokim zakresie analizowanych stężeń, dzięki czemu stosować można jeden zestaw krzywych wzorcowych (po jednej dla każdego składnika) w całym zakresie zmienności składu gazu ziemnego, bez negatywnego wpływu na uzyskiwaną niepewność ciepła spalania. Natomiast wykorzystanie jednopunktowej strategii wymaga dużej dbałości w doborze składu gazowych mieszanin wzorcowych. Nieodpowiedni dobór gazowej mieszaniny wzorcowej może powodować, że niepewność wyznaczenia ciepła spalania, związana z zastosowaną strategią wzorcowania, sięgać może nawet $0,8 \%$, co w przypadku gazów ziemnych należących do grupy E odpowiada około
0,3 $\mathrm{MJ} / \mathrm{m}^{3}$. W przypadku wzorcowania jednopunktowego trzeba każdorazowo sprawdzić, jak dobór gazowej mieszaniny wzorcowej wpływa na niepewność uzyskiwanych wyników w całym zakresie analizowanych stężeń. Należy wziąć pod uwagę również fakt, że w przypadku dużej zmienności składu gazów konieczne może być stosowanie więcej niż jednej gazowej mieszaniny wzorcowej do wzorcowania chromatografów gazowych, służących do analizy jednej grupy gazów. Dzieje się tak, ponieważ analizy składu gazów ziemnych - nawet wtedy, gdy pochodzą one z jednego obszaru rozliczeniowego - wymagać mogą więcej niż jednej gazowej mieszaniny wzorcowej stosowanej podczas wzorcowania jednopunktowego danego składnika. Może to w znacznym stopniu utrudniać prowadzenie analiz, szczególnie w przypadkach, gdy zmiany składu gazu następują w czasie i nie są bezpośrednio związane z miejscem poboru próbek gazu do badań.

Prosimy cytować jako: Nafta-Gaz 2015, nr 5, s. 322-328, DOI: 10.18668/NG.2016.05.03

Artykuł nadesłano do Redakcji 9.11.2015 r. Zatwierdzono do druku 8.03.2016 r.

Artykuł powstał na podstawie pracy statutowej pt. Wpływ strategii wzorcowania w analizach chromatograficznych gazu na niepewność wyznaczania jego parametrów energetycznych - praca INiG - PIB na zlecenie MNiSW; nr zlecenia: 0043/GE/15, nr archiwalny: DK-4100-43/15.

\section{Literatura}

[1] Holewa J.: Dobór analizatorów gazu pod kątem optymalizacji niepewności wyznaczenia parametrów energetycznych gazu. Dokumentacja INiG, Kraków 2013, nr zlecenia: 11/GE/13, nr archiwalny: DK-4100-11/13, s. 18-27.

[2] Holewa J., Szlęk M.: Ocena jakości gazów palnych. Nafta-Gaz 2013, nr 6, s. 450-454.

[3] Schuster T., Bogucki A.: Monitoring parametrów cieplnych gazu ziemnego $w$ systemach dystrybucyjnych $w$ kontekście rozliczeń energetycznych. Nafta-Gaz 2012, nr 9, s. 623-630.

[4] Schuster T., Bogucki A.: Trzy lata monitoringu parametrów cieplnych gazu ziemnego w krajowym systemie dystrybucyjnym. Nafta-Gaz 2011, nr 12, s. 909-919.

[5] Wieczorkowska G., Kochański P., Eljaszuk M.: Statysty$k a$ - wprowadzenie do analizy danych sondażowych $i$ eksperymentalnych. Wydawnictwo Naukowe Scholar, Warszawa 2003.

Mgr Jadwiga HOLEWA-RATAJ

Starszy specjalista badawczo-techniczny w Zakładzie Ochrony Środowiska.

Instytut Nafty i Gazu - Państwowy Instytut Badawczy

ul. Lubicz 25 A

31-503 Kraków

E-mail:jadwiga.holewa@inig.pl

\section{Akty prawne i normatywne}

[6] PN-EN ISO 10723:2013 Gaz ziemny - Ocena działania dotyczaca układów analitycznych.

[7] PN-EN ISO 6976:2008P Gaz ziemny - Obliczanie wartości kalorycznych, gęstości, gęstości względnej i liczby Wobbego na podstawie sktadu.

[8] Rozporzadzenie Ministra Gospodarki z dnia 2 lipca 2010 r. w sprawie szczegółowych warunków funkcjonowania systemu gazowego (Dz. U. z 2010 r. nr 133, poz. 891) z późniejszymi zmianami (Dz. U. z 2012 r., poz. 968).

[9] Rozporządzenie Ministra Gospodarki z dnia 28 czerwca 2013 r. w sprawie szczegółowych zasad kształtowania i kalkulacji taryf oraz rozliczeń w obrocie paliwami gazowymi (Dz. U. z 2013 r., poz. 820).

[10] ST-IGG-0205:2011 Ocena jakości gazów ziemnych. Część 1: Chromatografy gazowe procesowe do analizy sktadu gazu ziemnego.

[11] ST-IGG-2701:2014 Zasady rozliczeń paliw gazowych w jednostkach energii.

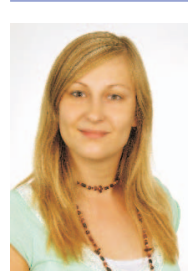

Magdalena WIŚNIECKA

Starszy specjalista badawczo-techniczny w Zakładzie Ochrony Środowiska.

Instytut Nafty i Gazu - Państwowy Instytut Badawczy ul. Lubicz 25 A

31-503 Kraków

E-mail:magdalena.wisniecka@inig.pl 